\title{
Traffic Education for Inexperienced Drivers with Virtual Driving Simulator
}

\author{
DIsmail Oztel ${ }^{1}$, (D)Cemil Oz ${ }^{2}$ \\ ${ }^{1}$ Corresponding Author; Computer Engineering Department, Sakarya University, Serdivan, Sakarya; \\ ioztel@sakarya.edu.tr; https://orcid.org/0000-0001-5157-7035; +902642953240 \\ ${ }^{2}$ Computer Engineering Department, Sakarya University, Serdivan, Sakarya; \\ https://orcid.org/0000-0001-9742-6021; coz@sakarya.edu.tr
}

Received 18 July 2019; Revised 9 August 2019; Accepted 27 August 2019; Published online 29 August 2019

\begin{abstract}
The numbers of vehicles in the traffic and population density have been increased with rising affluence. Besides this situation, people don't have enough information about the traffic. In 2017, the number of road accidents was 1.202.716 in Turkey according to the General Directorate of Highways. World Health Organization's data says that worldwide the total number of road traffic deaths is about 1.35 million per year. Along with these motivations, we developed a system for traffic education with both theoretical and practical exercises. The theoretical part of the system includes some tests which are about traffic, engine of vehicle and first aid information. The theoretical system has 10 test questions for each user. Another part of the system is a simulator with software and hardware. Firstly, in the system, a user answers the tests and the user needs to get at least 70 points in order to pass the second stage. Then, the user can use the simulator. The simulator includes a steering wheel, a pedal system, a shift knob, a driver seat, a visual display and a virtual platform with software. Owing to proposed system, inexperienced drivers will be able to acquire experience.
\end{abstract}

Keywords: driving simulator, driver education, virtual reality, traffic accident prevention

\section{Sanal Sürücü Simülatörü ile Acemi Sürücüler için Trafik Eğitimi}

\section{Öz}

Trafikteki araç sayısı ve şehirlerdeki nüfus yoğunluğu refah seviyesindeki yükseliş ile birlikte artmaktadır. Bu durumunun yanında insanlar trafik ile ilgili yeterince bilgi sahibi değildir. Karayolları Genel Müdürlüğü'ne göre Türkiye'deki trafik kazalarının 2017 yılındaki sayısı 1.202.716'dır. Dünya Sağlık Örgütü'nün verilerine göre dünya çapındaki trafik kazalarındaki ölüm sayıları her yıl yaklaşık olarak 1.35 milyondur. Bu bilgiler göz önünde tutulduğunda trafik eğitiminin önemi ön plana çıkmaktadır. Bu amaçla, bu çalışma kapsamında teorik ve pratik olmak üzere bir trafik eğitim sistemi geliştirilmiş̧tir. Sistemin teorik ayağında trafik, motor ve ilkyardım bilgisi olmak üzere üç konu başlıklı testler yer almaktır. Teorik aşama her kullanıcı için 10 adet test içermektedir. Sistemin diğer bir parçası ise sistemin donanımsal ayağı ve simülasyon yazılımından oluşmaktadır. Sistemin genel olarak kullanımında, bir kullanıcı ilk olarak üç konu başlığında girdiği test sınavında \%70 oranında başarılı olmalıdır. Bu şartı sağladıktan sonra kullanıcı simülatör eğitimine geçebilir. Simülatör direksiyon, pedal sistemi, vites kolu, sürücü koltuğu, simülasyon ekranı ve sanal ortam yazılımlarından oluşmaktadır. Bu sistem sayesinde acemi sürücüler gerçek hayatın risklerinden uzak olarak tecrübe kazanmaları mümkün olacaktır.

Anahtar kelimeler: Sürücü simülatörü, sürücü eğitimi, sanal gerçeklik, trafik kazalarını önleme

\section{Introduction}

Numbers of the vehicles in the traffic and population density in settlements increase with rising affluence. Depending on this situation, traffic flow has become complex. In addition, traffic flow is more complicated with unconscious drivers and pedestrians. In this complex traffic conditions, traffic accident numbers are increasing day by day. An example of the situation is shown in Table 1 [1]. As can be seen in the table, numbers of the accidents have increased per year in Turkey. In 2017, the number 
of road accidents was 1.202.716 in Turkey. According to the World Health Organization, the number of accidents with death is almost 1.35 million per year around the world [2]. One way to reduce the numbers and financial losses caused by accidents is to educate people about traffic. Driving simulator can be a successful way in order to educate people.

Table 1. General Statistics of Accidents Between 2008 and 2017 from Turkey

\begin{tabular}{c|c|c|c}
\hline Year & Number of Accidents & Number of Death & Number of Injured \\
\hline 2008 & 950.120 & 4.236 & 184.468 \\
\hline 2009 & 1.053 .346 & 4.324 & 201.380 \\
\hline 2010 & 1.104 .388 & 4.045 & 211.496 \\
\hline 2011 & 1.228 .928 & 3.835 & 238.074 \\
\hline 2012 & 1.296 .634 & 3.750 & 268.079 \\
\hline 2013 & 1.207 .354 & 3.685 & 274.829 \\
\hline 2014 & 1.199 .010 & 3.524 & 285.059 \\
\hline 2015 & 1.313 .359 & 3.831 & 304.421 \\
\hline 2016 & 1.182 .491 & 3.493 & 300.812 \\
\hline 2017 & 1.202 .716 & 3.534 & 300.383 \\
\hline
\end{tabular}

Simulations and simulators provide to educate people without the dangers of real life [3] [4]. Also, these are less costly than the real life [5] and simulations/simulators are good and easy way in order to collect some data for analyzing [6]. For example, some behaviors of drivers can be measured and analyzed with data which are collected the driving simulator. The behaviors can be stress, driving skills and so on [7].

In the literature, there are many driving simulator studies [8-10]. In our previous work, we developed a driving simulator for educational purpose [11]. In this study, users use the simulator and get some penalty points if they make any mistake. The aim of this simulation is to create a sense of realty and to gain familiarity with traffic information. In 2015, Meuleners and Fraser presented a study [12] which is about driving errors with the aid of driving simulator. In the study, 47 drivers were selected and all of them completed a survey. After this procedure, the differences on-road driving behaviors and driving simulator were investigated. According to the results, there is no difference between simulator driving and on-road driving behavior for observation of outside of a vehicle, the average speed of junction, carry on speed and comply with traffic signs and lights. Bella et al. conducted a study (2014) about driving speed under dark conditions using driving simulator [13]. In the study, drivers' speed levels were compared under day time and night time conditions. For 40 participants, speed levels of them were recorded. In conclusion, they presented a table in their paper. According to the table, the speeds of day time are higher than the night time under different parameters. Imamura et al. has a study [14] for traffic safety education. They proposed a driving simulator in order to educate people for traffic safety. Their participants were some high school students. They tested the effectiveness of the simulator with a survey. A study [15] of Backlund et al. is about traffic safety. There is a car simulator in their study and owing to the simulator, their system collected data that is about safety variables which are speed level, some distances in traffic, line tracking behavior, etc. The collected data were analyzed after simulations and safety variables were examined for the relationship between them. In conclusion, they suggested simulations, which are game based, for the purpose of education. Rosey and Auberlet's paper [16] includes two studies. In the first study, 23 participants used a simulator which includes a steering wheel, a pedal system, a shift knob, a computer, and three monitors in order to reflect the virtual world. In the second one, 24 participants use a simulator that is used a real vehicle cabin. In both scenarios, the same database was used. The aim of this studies is to asses control situations and behavior of drivers in the both type of simulators. One of the results of this study is drivers' behaviors were not properly at intersections on the desktop simulator. Another result is about speed level. The level was higher when used the desktop simulator than the other. Lauritsen and Hansen proposed a study [17] in order to assess of patients' driving skills using a driving simulator. According to the results of the study, the driving tests in a simulator can show changefulness for drivers with some diseases. Wang et al. examined the effect of culture on driving behavior under critical situations and they used a driving simulator for this purpose [18]. Results showed that behavior of people with different culture, gender and age have acted different when using the simulator under different scenarios. 
Oztel et. al

The contributions of our study can be summarized as follows:

1. The proposed simulator can educate people for the traffic rules using penalty warnings.

2. In contrast to other simulator studies, we measure theoretical knowledge as well as practical knowledge in the proposed system with a theoretical test part.

\section{The System Description}

\subsection{The Application Background}

Our developed system has some parts which are part of a theoretical tests on a web site, virtual platform, and hardware of the simulator.

In the theoretical tests, the system has a lot of questions which are divided into three groups. A group of these tests is about traffic information, another one is about engine of vehicle information and the last group is about first aid information. Each group has ten tests and each test has ten questions. A user can answer a question at one time in the system. For testing stage, we developed a survey site using ASP.NET and MsSql database.

The virtual platform includes some traffic signs, signaling system, object of traffic in order to perform some driving tests. Figure 1 shows bird's eye view of virtual test platform. We used the Sketchup 3D modeling program to generate the platform. Some buildings, signaling system, roads, traffic signs, some vehicles were modeled on the Sketchup. The virtual test platform was used on Unity Game Engine in order to use the virtual environment for driving tests. 3D models were designed on the Sketchup which has .skp file extensions to export the designed models but the game engine doesn't run with .skp file extension. The models were exported with .fbx file extension from the Sketchup. Thus, the models are ready to use on the Unity. We used Unity Asset Store for car that is used in the simulation. Java programming language was used for codding the simulation.

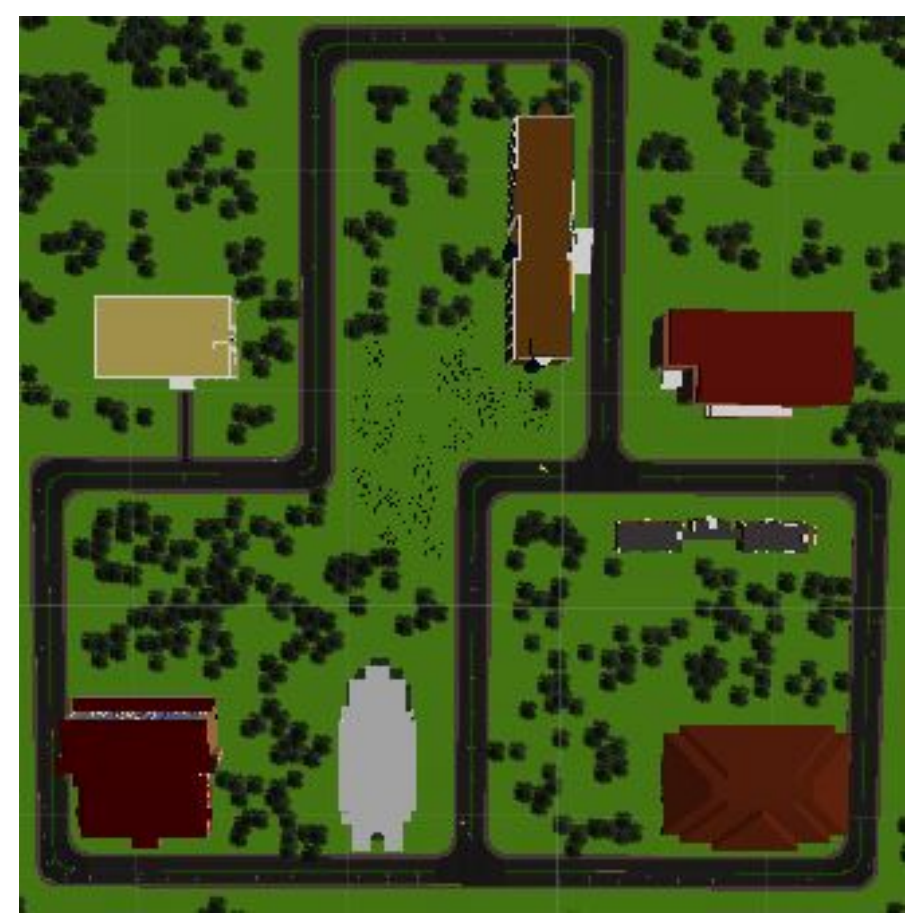

Figure 1 A sample view of the virtual platform

Part of the hardware of the system has a lot of partitions which are a visual display, a computer, a driver seat, a steering wheel, a pedal system, and a shift knob. The set of that is steering wheel, pedal system 
Oztel et. al

and shift knob group is Logitech G25 Racing Wheel. Pedal system contains gas, brake and clutch pedals. The system is shown in Figure 2.

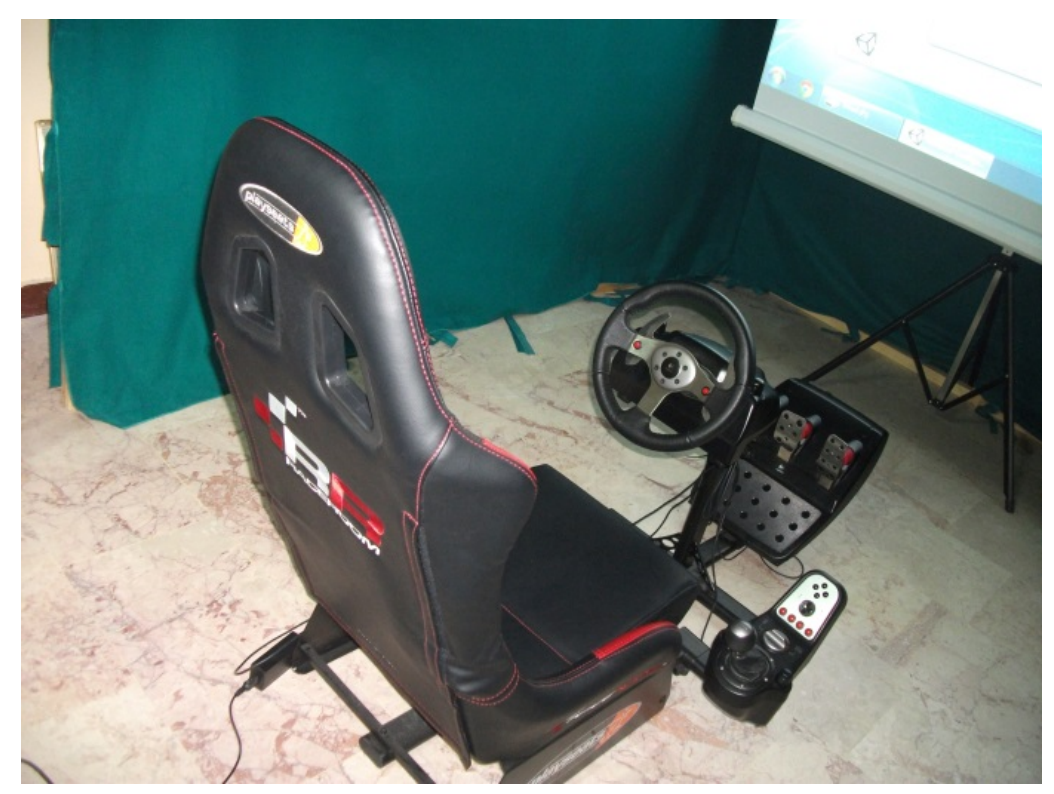

Figure 2 A sample view of the hardware system

\subsection{The Scenario}

In order to use the system, a user firstly must register, then the user answer ten questions are about first aid information. The user has ten minutes to answer the questions. After answering the questions, the user goes to other ten questions which are about traffic information on the web site and the user has ten minutes again. After that, engine of vehicle information's questions are answered in ten minutes by the user. Following the thirty questions, the user gets a score. If the score is greater than 70 , the user deserves to use the simulator. If the score isn't greater 70, the user answers another thirty questions. A user can take maximum 10 exams. Figure 3 shows an example of theoretical tests. Every user's data is collected with details by a database.

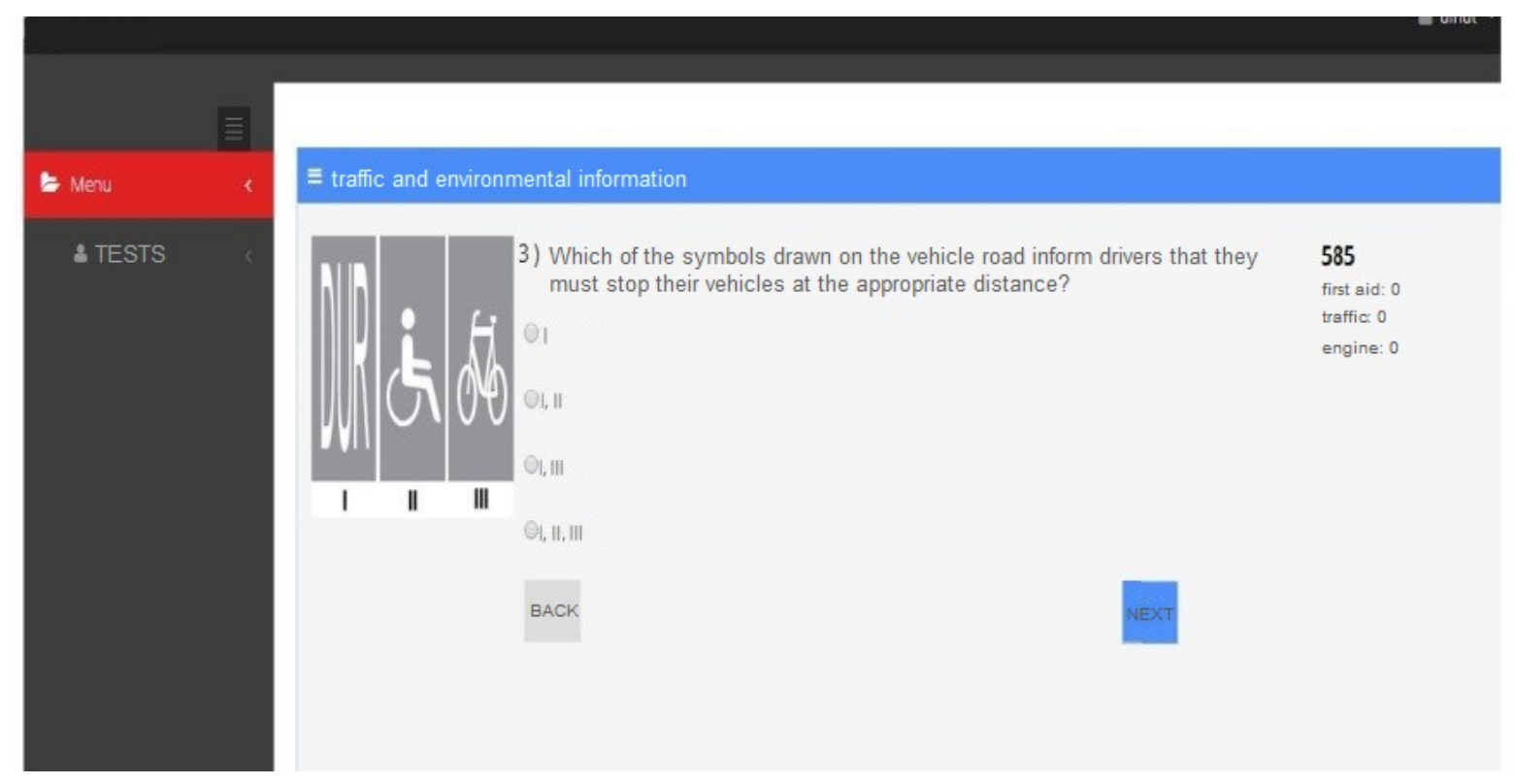

Figure 3 A sample view of the web site for test-purpose 
Oztel et. al

After the theoretical part, the simulation part starts. In this section, a user drives a car. If the user makes a mistake about traffic rules, the simulation program gives penalty points to him/her. For example, a driver runs a red light, the program gives penalty points according to the Turkish National Police Traffic Service Department's penalty guide [19]. In Table 2, there are some penalty points of the penalty guide. The purpose of this section is completed the course without any or few mistakes. Figure 4 shows a scene in the simulation.

Table 2 Some penalty points according to the penalty guides

\begin{tabular}{c|c}
\hline Breach Subjects & Penalty Points \\
\hline Failure to comply with the red light rules & 20 \\
\hline Failure to comply with traffic signboards & 20 \\
\hline To exceed the speed limit by up to \%30 from \%10 & 10 \\
\hline To exceed the speed limit by more than \%30 & 15 \\
\hline Move from one place where is forbidden to pass & 20 \\
\hline Failure to comply with line change and tracking rules & 20 \\
\hline Dangerous driving & 10 \\
\hline Failure to comply with the rules of turn(right or left) & 20 \\
\hline
\end{tabular}

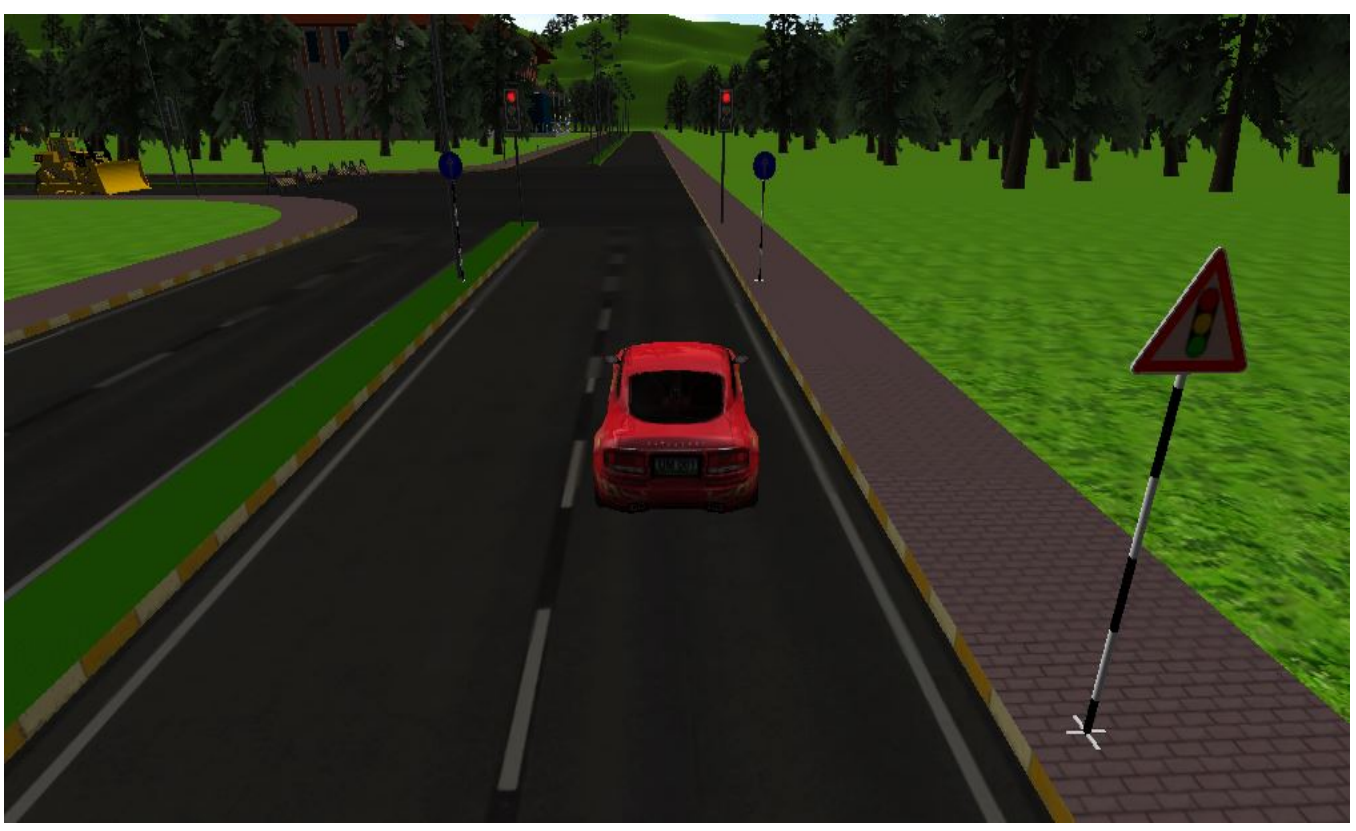

Figure 4 A sample image during the simulation

\section{Conclusion}

In this study, we proposed a simulator in order to educate and gain experience for inexperienced drivers. In this context, we prepared a virtual environment for driving simulation. Sketchup 3D modeling program was used for this purpose. The virtual platform is an area which includes some builds, traffic signs, traffic signalization systems, vehicles, and natural objects. The platform was transferred on the Unity Game Engine for simulation. A car was used from Unity Asset Store. Javascript was used for coding process in Unity. Furthermore, we developed a web site in order to evaluate the participants' information about traffic, engine of vehicle and first aid information. In this part, every user has to take a three stage test and every test has ten questions about the three topics. After completing the test, if the user takes at least 70 point out of a hundred, he/she may pass to the simulation. In the simulation step, a user uses the driving simulator. The virtual environment has traffic rules and the user takes penalty points for every mistake. For example, if the driver runs a red light, then 20 penalty points are given by the simulator. Penalty points were taken from Turkish traffic rules. 
Owing to our system, a user gain experience which can be associated with driving skills and traffic rules. At the same time, training takes places without real life risks. In the system, educating process is performed in a fun way. The next goal of the project is adding some cars with artificial intelligence and trying the system validation with some participants.

\section{References}

[1] The General Directorate of Highways, "traffic accidents summary," 2014. [Online]. Available: www.kgm.gov.tr/SiteCollectionDocuments/KGMdocuments/Trafik/TrafikKazalariOzeti2017.pdf. [Accessed: 09/08/2019].

[2] World Health Organization, "Road traffic injuries,". [Online]. Available: https://www.who.int/news-room/fact-sheets/detail/road-traffic-injuries. [Accessed: 09/08/2019].

[3] B. Reımer, L. A. D'ambrosı, J. E. Coughlın, M. E. Kafrıssen, And J. Biederman, "Using SelfReported Data to Assess the Validity of Driving Simulation Data.," Behavior Research Methods, vol. 38, no. 2, pp. 314-324, 2006.

[4] A. Calvi and F. Bella, "Modeling Speed Differential Parameters in Day and Night Environments Using Driving Simulator," Procedia Engineering, vol. 84, pp. 648-661, 2014.

[5] M. Ristoa ve M. H. Martens, «Driver Headway Choice: A Comparison Between Driving Simulator and Real-Road Driving,» Transportation Research Part F: Traffic Psychology and Behaviour, 25, pp. 1-9, 2014.

[6] F. Bella, "Driver perception hypothesis: Driving simulator study," Transportation Research Part F: Traffic Psychology and Behaviour, vol. 24, pp. 183-196, 2014.

[7] Hans Antonsona, A. Jägerbrand ve C. Ahlström, ”Experiencing Moose and Landscape While Driving: A Simulator and Questionnaire Study,” Journal of Environmental Psychology, 41, pp. 91-100, 2015.

[8] C. Ahlström, A. Anund, C. Fors, and T. Åkerstedt, "The effect of daylight versus darkness on driver sleepiness: a driving simulator study,” J. Sleep Res., vol. 27, no. 3, p. e12642, Jun. 2018.

[9] A. Dosovitskiy, G. Ros, F. Codevilla, A. Lopez, and V. Koltun, "CARLA: An Open Urban Driving Simulator,” ArXivID: 1711.03938, Nov. 2017.

[10] W. Wang, Q. Cheng, C. Li, D. André, and X. Jiang, "A cross-cultural analysis of driving behavior under critical situations: A driving simulator study,” Transp. Res. Part F Traffic Psychol. Behav., vol. 62, pp. 483-493, Apr. 2019.

[11] I. Oztel Ve C. Oz, "Developing a Virtual Driving Simulator for Educational Purposes,” Balkan Journal of Electrical \& Computer Engineering, 2, no. 2, pp. 51-54, 2014.

[12] L. MeulenerS ve M. Fraser, “A Validation Study of Driving Errors Using a Driving Simulator,” Transportation Research Part F: Traffic Psychology and Behaviour, 29, pp. 14-21, 2015. 
[13] F. Bella, A. Calvi ve F. D'Amico, "Analysis of Driver Speeds Under Night Driving Conditions Using a Driving Simulator,” Journal of Safety Research, 49, pp. 45-52, 2014.

[14] T. Imamura, T. Ogi, E. T. C. Lun, Z. Zhang Ve T. Miyake, "Trial Study of Traffic Safety Education for High School Students Using Driving Simulator," in Proceedings of the 2013 IEEE International Conference on Systems, Man, and Cybernetics, 2013.

[15] P. Backlund, H. Engstrom, M. Johannesson Ve M. Lebram, "Games and Traffic Safety - an Experimental Study in a Game-Based Simulation Environment,” Information Visualization, 2007. IV '07. 11th International Conference, Zurich, 2007.

[16] F. Rosey ve J.-M. Auberlet, "Driving Simulator Configuration Impacts Drivers’ Behavior And Control Performance: An Example with Studies of a Rural Intersection,” Transportation Research Part F: Traffic Psychology and Behaviour, 27, pp. 99-111, 2014.

[17] J. Lauritsen and M. Hansen, "PW 2532 Use of a car-driving simulator in rehabilitation and driving assessment of patients after trauma,” in Abstracts, 2018, p. A260.2-A261.

[18] W. Wang, Q. Cheng, C. Li, D. André, and X. Jiang, “A cross-cultural analysis of driving behavior under critical situations: A driving simulator study,” Transp. Res. Part F Traffic Psychol. Behav., vol. 62, pp. 483-493, Apr. 2019.

[19] The General Directorate of Security, “2019 Y11ı Trafik Ceza Rehberi,”. [Online]. Available: https://www.egm.gov.tr/trafik-cezalari-hakkinda-bilgi-almak-istiyorum. [Accessed: 09/08/2019]. 